\title{
Pengaruh Intellectual Capital dan Rata - Rata/Pertumbuhannya (Rogic) Terhadap Kinerja Bank Syariah Berdasarkan Islamicity Performance Index di Indonesia
}

\author{
Sasiska Rani ${ }^{1}$, Martha Rianty N. $^{2}$ \\ ${ }^{1}$ Jurusan Akuntansi, Universitas Tridinanti Palembang \\ Email: sasiska_rani@univ-tridinanti.ac.id \\ ${ }^{2} J u r u s a n$ Akuntansi, Universitas Tridinanti Palembang \\ Email: martharianty@univ-tridinanti.ac.id
}

\begin{abstract}
This study examines the effect of intellectual capital and the average growth intellectual capital (ROGIC) on the performance of Syariah Banks based on the Islamicity Performance Index in Indonesia. The Islamicity Performance Index in this study is proxied by the Profit Sharing Ratio (PSR). The sample obtained was based on the purposive sampling technique in this study, namely 10 Syairah Banks from 2015 - 2019. This study used data analysis techniques in the form of multiple regression analysis. The results show that there is a negative effect between intellectual capital on the Islamicity Performance Index, which is proxied by the Profit Sharing Ratio (PSR). The average growth of intellectual capital (ROGIC) has a positive effect on the Islamicity Performance Index, which is proxied by the Profit Sharing Ratio (PSR).
\end{abstract}

Keyword : Intellectual capital, average growth intellectual capital (ROGIC), Islamicity Performance Index

\begin{abstract}
ABSTRAK
Penelitian ini meneliti tentang pengaruh intellectual capital dan rata - rata pertumbuhan intellectual capital (ROGIC) terhadap kinerja Bank Syariah berdasarkan islamicity performance index di Indonesia. Islamicity performance index dalam penelitian ini diproksi dengan profit sharing ratio (PSR). Sampel yang diperoleh berdasarkan teknik purposive sampling dalam penelitian ini yaitu 10 Bank Syairah dari tahun 2015 - 2019. Penelitian ini menggunakan teknik analisis data berupa analisis regresi berganda. Hasil penelitian menunjukkan bahwa terdapat pengaruh negatif antara intellectual capital terhadap islamicity performance index yang diproksi dengan profit sharing ratio (PSR). Rata - rata pertumbuhan intellectual capital (ROGIC) berpengaruh positif terhadap islamicity performance index yang diproksi dengan profit sharing ratio (PSR).
\end{abstract}

Kata kunci: Intellectual capital, Rata - Rata Pertumbuhan Intellectual Capital (ROGIC), Islamicity Performance Index 


\section{Pendahuluan}

Fenomena yang terjadi dalam beberapa dekade belakangan ini yaitu berkembang dengan pesatnya Bank Syariah di Indonesia. Oleh karena itu, perbankan syariah perlu untuk terus memperbaiki kinerjanya untuk menciptakan perbankan syariah yang efisien dan sehat [1]. Untuk mencapai kinerja yang baik dalam mengelola Bank Syariah diperlukan sumber daya manusia yang memiliki kompetensi dibidang perbankan syairah. Permasalahan utama terhambatnya pertumbuhan kinerja pada Bank Syariah disebabkan karena kurang tersedianya sumber daya manusia yang mempunyai kompetensi dibidang perbankan syariah.

Kinerja pada bank yang berbasis perbankan syariah dapat ditingkatkan jika pihak bank mampu mengubah manajemen yang berbasis pada tenaga kerja menjadi manajemen yang berbasis pada pengetahuan [2]. Revolusi Industri 4.0 mendukung hal tersebut yaitu perusahaan harus mempunyai sumber daya manusia yang berkualitas dan berkompeten. Dengan adanya kemampuan sumber daya manusia yang baik, diharapkan menghasilkan kinerja yang baik bagi perusahaan [3]. Sumber daya manusia dalam akuntansi tergolong sebagai aset tak berwujud. Intellectual capital merupakan salah satu pendekatan dalam melakukan penilaian dan pengukuran aset tak berwujud [4]-[6]

Menurut International Federation of Accountant (IFAC) intellectual capital merupakan intellectual property, intellectual asset, knowledge asset yang dapat diartikan sebagai saham atau modal yang berbasis pada pengetahuan yang dimiliki perusahaan. Intellectual capital adalah pengetahuan yang dimiliki oleh seseorang yang akan berkontribusi terhadap keunggulan kompetitif perusahaan [7]. Intellectual capital dapat meliputi pengetahuan, kompetensi, kekayaan intelektual, merek, reputasi, dan hubungan pelanggan [8]. Oleh sebab itu, untuk dapat meningkatkan nilai perusahaan serta perusahaan dapat unggul dalam berkompetitif, perusahaan dituntut untuk dapat memaksimalkan pengelolaan sumber daya yang ada pada setiap individu [9]

Selain intellectual capital, rata - rata pertumbuhan intellectual capital (ROGIC) juga dapat mempengaruhi kinerja Bank Syariah. Kinerja yang lebih baik ditunjukkan oleh perusahaan yang memiliki intellectual capital yang terus meningkat, sehingga terdapat hubungan yang positif dengan kinerja masa depan [10].

Intellectual capital (IC) menjadi faktor yang dapat mengukur kinerja Bank Syariah. Untuk memperoleh kepercayaan dari stakeholders perkembangan Bank Syariah harus disertai dengan perkembangan kinerja yang baik. Penilaian pada kinerja Bank Syariah harus sesuai dengan prinsip - prinsip syariah [11]. Kinerja Bank Syariah dapat diukur dengan menggunakan islamicity performance index yang dapat diproksi dengan profit sharing ratio [12].

Penelitian mengenai intellectual capital dan rata - rata pertumbuhan intellectual capital untuk mengukur kinerja suatu perusahaan telah banyak dilakukan di Indonesia baik pada sektor jasa dan lembaga keuangan konvensional maupun syariah seperti yang dilakukan oleh Baroroh (2014); Harianto \& Syafruddin (2013); Nazra \& Suazhari (2019); Oniva et al. (2019); Ramadhanty (2018); Riyandini et al. (2015); Zulaecha \& Pantori (2015) namun hasilnya masih menunjukkan perbedaan.

Intellectual capital dan rata - rata pertumbuhan intellectual capital (ROGIC) menjadi faktor yang menarik untuk mengukur kinerja Bank Syariah. Hal ini dikarenakan masih terbatasnya sumber daya manusia yang memiliki pengetahuan dan 
berkompeten dibidang perbankan syariah. Masih banyak terdapatnya sumber daya manusia yang mengelola perbankan syariah dengan latar bekalang pengetahuan dan kompetensi dari bank konvensional.

Berdasarkan uraian tersebut, peneliti tertarik untuk meneliti mengenai pengaruh intellectual capital (IC) dan rata - rata pertumbuhan intellectual capital (ROGIC) terhadap kinerja Bank Syariah berdasarkan islamicity performance index di Indonesia.

\section{Landasan Teori}

\section{Resource Based Theory}

Dalam resource based theory mengungkapkan bagaimana perusahaan mampu menciptakan keunggulan dalam bersaing di dunia usaha dengan mengelola sumber daya yang ada di perusahaan seefektif dan seefisien mungkin. Kemampuan dalam mengelola sumber daya yang baik akan menciptakan sumber daya yang berkompeten yang mampu mengantarkan perusahaan menjadi yang terunggul dari pesaing pesaingnya dan akhirnya akan membawa perusahaan memiliki kinerja yang baik.

Salah satu sumber daya dalam hal ini adalah sumber daya manusia yang dimiliki oleh perusahaan. Salah satu kunci yang dapat menciptakan value added pada perusahaan adalah intellectual capital yang ada dalam sumber daya manusia [19]. Pendekatan resource based theory menjelaskan dengan pengelolaan dan pengendalian aset yang strategis, baik aset yang berwujud maupun aset tak berwujud dapat menghantarkan perusahaan memenangkan persaingan secara berkesinambungan serta mencapai tujuan perusahaan yaitu memperoleh keuntungan semaksimal mungkin [20]. Intellectual capital merupakan aset tak berwujud yang diklasifikasikan dalam tiga kategori utama yaitu human capital, structural capital, dan capital employed. Pemanfaatan ketiga sumber daya tersebut secara efektif dan efisien untuk meningkatkan kinerja perusahaan.

\section{Islamicity Performance Index}

Pengukuran kinerja keuangan Bank Syariah mempunyai sifat yang berbeda dengan bank konvensional. Oleh karena itu dibutuhkan alat ukur kinerja yang sesuai dengan sifat perbankan syariah. Islamicity performance index merupakan indeks untuk mengukur kinerja perbankan syariah. Indeks pengukuran ini dikembangkan oleh Hameed et al. (2004). Pengukuran kinerja menggunakan islamicity performance index tidak hanya melihat dari sisi materialitas saja, tetapi juga dari sisi spiritual. Berdasarkan islamicity performance index, kinerja perbankan syariah diukur berdasarkan prinsip - prinsip syariah [11], [12], [14], [21].

Hameed et al., (2004) telah mengembangkan suatu indeks yang dapat digunakan untuk melakukan pengukuran kinerja perbankan syariah yang sesuai dengan sifat umum dari bank syariah itu sendiri. Index ini dapat dipergunakan untuk mengukur rasio-rasio yang dapat menggambarkan cerminan dari business performance perbankan syariah. Salah satu islamicity performance index yang dapat digunakan untuk mengukur kinerja Bank Syariah yaitu profit sharing ratio (PSR). Rasio PSR digunakan untuk mengidentifikasi keberhasilan Bank Syariah dalam mencapai tujuan atas eksistensinya. Rasio PSR menggambarkan kinerja Bank Syariah dalam menyalurkan dananya ke sektor publik serta memberikan informasi mengenai tingkat pembiayaan di Bank Syariah [14]. 


\section{Pengertian Intellectual Capital (IC)}

Menurut International Federation of Accountant (IFAC) intellectual capital merupakan modal yang berdasarkan pada pengetahuan yang dimiliki perusahaan yang berupa intellectual property, intellectual asset, dan knowledge asset. Intellectual capital merupakan sumber daya yang tak berwujud yang dimiliki oleh perusahaan berupa pengetahuan yang akan menjadi value added bagi perusahaan untuk meningkatkan kinerja perusahaan.

Ada tiga bagian utama dari intellectual capital [22], yaitu:

1. Human capital (HC) merupakan sumber daya kunci yang dapat menciptakan keunggulan kompetitif perusahaan sehingga perusahaan mampu bersaing dan bertahan di lingkungan bisnis yang dinamis. Dengan mempunyai karyawan yang berkeahlian dan berketerampilan, kinerja perusahaan dapat ditingkatkan sehingga dapat menjamin keberlangsungan hidup perusahaan.

2. Structural capital merupakan kemampuan organisasi berkaitan dengan memaksimalkan aktivitas perusahaan dan kinerja intelektual serta kinerja bisnis secara utuh.

3. Relational capital (RC) atau customer capital (CC) merupakan kesinambungan hubungan yang ada di perusahaan dengan para mitranya, seperti pelanggan, supllier, pemerintah, dan lain - lain.

\section{Value Added Intellectual Coefficient (VAICTM)}

Value added intellectual coefficient (VAICTM) dikembangkan oleh Pulic, 1998 didesain sebagai metode untuk menyajikan informasi tentang value creation efficiency dari asset berwujud (tangible asset) dan asset tidak berwujud (intangible asset) yang dimiliki perusahaan. VAICTM merupakan salah satu item yang dapat digunakan untuk melakukan pengukuran kinerja intellectual capital perusahaan. Keunggulan metode VAIC ${ }^{\mathrm{TM}}$ menggunakan data yang berasal dari berbagai sumber dan jenis perusahaan sehingga data mudah untuk didapat. Data yang dibutuhkan untuk menghitung berbagai rasio tersebut adalah angkaangka keuangan yang standar yang umumnya tersedia dari laporan keuangan perusahaan [10].

Value added dihitung sebagai selisih antara output dan input [23]. Hubungan kedua VA, satu modal fisik yang mempekerjakan (CA) disebut "nilai tambah modal koefisien" (VACA): Ini adalah indikator dari nilai tambah yang diciptakan oleh satu unit modal fisik:

$$
\text { VACA }=\mathrm{VA} / \mathrm{CE}
$$

Koefisien HC (VAHU) menunjukkan berapa banyak nilai tambah dihabiskan untuk karyawan:

\section{VAHU $=$ VA $/ \mathbf{H C}$}

Hubungan antara VA dan HC mengindikasikan kemampuan dari HC untuk menciptakan nilai dalam sebuah perusahaan. Langkah berikutnya adalah menetapkan kontribusi SC dalam penciptaan nilai. Dalam model Pulic itu, SC adalah VA-HC. HC dan SC adalah berbanding terbalik. STVA mengukur saham SC dalam penciptaan VA. Hubungan selanjutnya antara VA dan SC dihitung sebagai:

\section{STVA=SC/VA}


Value Added Intellectual Coefficient (VAICTM) mengindikasikan kemampuan intelektual organisasi. VAIC ${ }^{\text {TM }}$ juga dapat dianggap sebagai BPI (Business performance indicator).

\section{Rate Of Growth of Intellectual Capital (ROGIC)}

$$
\text { VAICTM = VACA + VAHU + STVA }
$$

Selain intellectual capital, rata - rata pertumbuhan intellectual capital (ROGIC) juga dapat mempengaruhi kinerja Bank Syariah. Perusahaan dengan intellectual capital yang terus meningkat akan cenderung memiliki kinerja yang baik, sehingga dapat disimpulkan bahwa rata - rata pertumbuhan intellectual capital juga akan mempengaruhi hubungan positif dengan kinerja masa depan [10].

$$
\text { ROGIC = } \text { VAIC }^{\text {TM }_{t}}-\text { VAIC }^{\text {TM }-1}
$$

\section{Kerangka Penelitian}

Berikut ini merupakan gambar kerangka penelitian dalam penelitian ini yaitu :

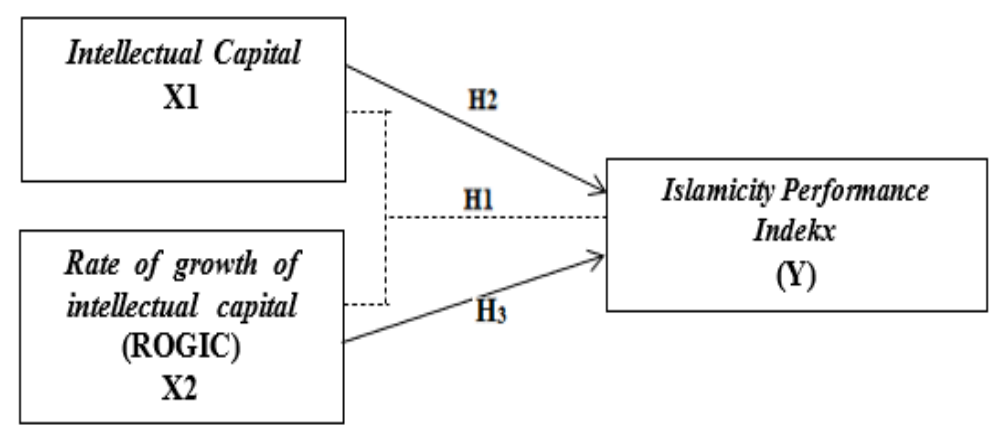

Gambar 1 Kerangka Penelitian

\section{Hipotesis Penelitian}

Hipotesis yang dapat dirumuskan dalam penelitian ini yaitu sebagai berikut :

$\mathrm{H}_{1} \quad$ : Terdapat pengaruh secara simultan antara intellectual capital dan rata - rata pertumbuhan intellectual capital (ROGIG) terhadap kinerja Bank Syariah berdasarkan Islamicity Performance Index di Indonesia

$\mathrm{H}_{2}$ : Terdapat pengaruh intellectual capital terhadap kinerja Bank Syariah berdasarkan Islamicity Performance Index di Indonesia

$\mathrm{H}_{3}$ : Terdapat pengaruh rata-rata pertumbuhan intellectual capital (ROGIC) terhadap kinerja Bank Syariah berdasarkan Islamicity Performance Index di Indonesia

\section{Metode Penelitian}

Penelitian ini menggunakan pendekatan kuantitatif yang menunjukkan hubungan antar variabel. Populasi yang digunakan yaitu Bank Umum Syariah yang terdaftar di Bank Indonesia tahun 2015 - 2019 yaitu sebanyak 14 bank. Purposive sampling digunakan sebagai teknik pengambilan sampel pada penelitian ini. Berdasarkan teknik pengambilan sampel maka sampel yang dapat digunakan digunakan dalam penelitian ini sebanyak 10 Bank Syariah. Dalam penelitian ini instrumen penelitian yang digunakan yaitu annual report dan laporan keuangan yang dipublikasikan oleh Bank Syariah di Indonesia. 
Teknik analisis data yang dilakukan dalam penelitian meliputi uji asumsi klasik dan uji regresi linier berganda. Uji asumsi klasik terdiri dari uji normalitas, uji multikoliniearitas, uji autokorelasi dan uji heteroskedastisitas. Adapun persamaan model regresi berganda dalam penelitian ini yaitu :

$$
\text { IPI }=\alpha+\beta_{1} I C+\beta_{2} \text { ROGIC }+\varepsilon
$$

Keterangan :

$\begin{array}{ll}\text { IPI } & =\text { Islamicity Performance Index } \\ \alpha & =\text { Konstanta } \\ \beta_{1,2} & =\text { Koefisien regresi } \\ \text { IC } & =\text { Intellectual Capital } \\ \text { ROGIG } & =\text { Rata }- \text { Rata Pertumbuhan Intellectual Capital } \\ \varepsilon & =\text { standar error }\end{array}$

\section{Hasil dan Pembahasan Uji Normalitas}

Untuk mengetahui apakah nilai residual data berdistribusi normal atau tidak maka dilakukan uji normalitas. Berdasarkan hasil analisis diperoleh hasil analisis uji normalitas sebagai berikut:

Tabel 1. Hasil Uji Normalitas

One-Sample Kolmogorov-Smirnov Test

\begin{tabular}{|c|c|c|}
\hline & & $\begin{array}{l}\text { Unstandardiz } \\
\text { ed Residual }\end{array}$ \\
\hline$N$ & & 49 \\
\hline \multirow[t]{2}{*}{ Normal Parameters ${ }^{a, b}$} & Mean & $0 E-7$ \\
\hline & Std. Deviation & , 13860201 \\
\hline \multirow[t]{3}{*}{ Most Extreme Differences } & Absolute & 170 \\
\hline & Positive & 170 \\
\hline & Negative &,- 095 \\
\hline Kolmogorov-Smirnov Z & & 1,189 \\
\hline Asymp. Sig. (2-tailed) & &, 118 \\
\hline
\end{tabular}

a. Test distribution is Normal.

b. Calculated from data.

Sumber : data diolah, 2021

Berdasarkan tabel 1 menunjukkan bahwa hasil pengujian dengan metode OneSample Kolmogorov - Smirnov Test sebesar 0,118 (Asymp. Sig. (2-tailed)) yang lebih besar dari 0,05 dan dapat dikatakan bahwa nilai residual terdistribusi secara normal.

\section{Uji Multikoliniearitas}

Ada atau tidaknya multikoliniearitas di dalam model regresi dapat dideteksi dengan melihat hasil perhitungan VIF (Variance Inflation Factor). Regresi bebas dari masalah multikoliniearitas jika $0,1<$ VIF $<10$. Berikut ini adalah hasil uji multikoliniearitas dalam penelitian ini : 
Tabel 2. Hasil Uji Multikoliniearitas

\begin{tabular}{|c|c|c|c|}
\hline & \multirow[t]{2}{*}{ Model } & \multicolumn{2}{|c|}{ Collinearity Statistics } \\
\hline & & Tolerance & VIF \\
\hline \multirow{3}{*}{1} & (Constant) & & \\
\hline & Lag_X1 & ,444 & 2,253 \\
\hline & Lag_X2 & ,444 & 2,253 \\
\hline
\end{tabular}

a. Dependent Variable: Lag_Y

Sumber : data diolah, 2021

Berdasarkan tabel 2 menunjukkan bahwa variabel independen, yaitu intellectual capital (X1) dan rata - rata pertumbuhan intellectual capital (X2) memiliki nilai VIF 2,253 . Berdasarkan hal tersebut dapat disimpulkan bahwa variabel independen yang digunakan dalam penelitian ini tidak memiliki korelasi atau hubungan yang erat satu sama lain sehingga tidak terjadi multikoloniearitas antar variabel independen dalam model penelitian.

\section{Uji Heteroskedastisitas}

Uji heteroskedastisitas bertujuan untuk menguji apakah dalam model regresi terjadi ketidaksamaan variance dari residual satu pengamatan ke pengamatan lain. Berikut ini hasil pengujian heteroskedastisitas pada penelitian ini :

Tabel 3. Hasil Uji Heteroskedastisitas dengan Uji Glejser

Coefficients $^{a}$

\begin{tabular}{|c|c|c|c|c|c|c|}
\hline \multirow[b]{2}{*}{ Mod } & & \multicolumn{2}{|c|}{ Unstandardized Coefficients } & \multirow{2}{*}{$\begin{array}{c}\text { Standardized } \\
\text { Coefficients }\end{array}$} & \multirow[b]{2}{*}{$\mathrm{t}$} & \multirow[b]{2}{*}{ Sig. } \\
\hline & & $\mathrm{B}$ & Std. Error & & & \\
\hline \multirow[t]{3}{*}{1} & (Constant) & 101 & ,020 & & 5,026 &, 000 \\
\hline & Lag_X1 &,- 006 &, 010 &,- 121 &,- 550 &, 585 \\
\hline & $\mathrm{Lag}_{-} \mathrm{X} 2$ & $5,505 \mathrm{E}-006$ &, 006 &, 000 &, 001 & ,999 \\
\hline
\end{tabular}

a. Dependent Variable: Abs_RES

Sumber : data diolah, 2021

Berdasarkan tabel 3 didapatkan nilai signifikansi (Sig.) untuk variabel X1 sebesar 0,585 dan untuk variabel x2 sebesar 0,999. Nilai signifikansi (Sig.) dari kedua variabel independen diatas $>0,05$. Berdasarkan hal tersebut dapat disimpulkan bahwa model regresi yang digunakan dalam penelitian ini tidak terdapat heteroskedastisitas.

\section{Uji Autokorelasi}

Uji autokolerasi dapat dilakukan dengan menggunakan uji run. Berikut ini hasil uji autokorelasi dalam penelitian ini : 
Tabel 4. Hasil Uji Autokorelasi

\begin{tabular}{|l|r|}
\hline \multicolumn{2}{|c}{ Runs Test } \\
\hline & $\begin{array}{r}\text { Unstandardiz } \\
\text { ed Residual }\end{array}$ \\
\hline Test Value &,- 00516 \\
Cases $<$ Test Value & 24 \\
Cases > = Test Value & 25 \\
Total Cases & 49 \\
Number of Runs & 20 \\
Z & $-1,441$ \\
Asymp. Sig. (2-tailed) &, 149 \\
\hline
\end{tabular}

a. Median

Sumber : data diolah, 2021

Berdasarkan tabel 4 hasil uji autokolerasi dengan menggunakan runs tes menunjukkan bahwa nilai signifikansi sebesar 0,149 $>0,05$ yang berarti tidak adanya autokolerasi pada model penelitian.

\section{Uji Regresi Linier Berganda}

Regresi linier berganda yang digunakan dalam penelitian ini bertujuan untuk mengetahui pengaruh intellectual capital (X1) dan rata - rata pertumbuhan intellectual capital (X2) terhadap kinerja Bank Syariah berdasarkan islamicity performance index. Hasil analisis regresi linier berganda pada penelitan sebagai berikut:

\section{Tabel 5. Hasil Uji Regresi Linier Berganda}

\begin{tabular}{|c|c|c|c|c|c|c|}
\hline \multicolumn{7}{|c|}{ Coefficients $^{a}$} \\
\hline \multirow{2}{*}{\multicolumn{2}{|c|}{ Model }} & \multicolumn{2}{|c|}{ Unstandardized Coefficients } & \multirow{2}{*}{$\begin{array}{c}\text { Standardized } \\
\text { Coefficients } \\
\text { Beta }\end{array}$} & \multirow[t]{2}{*}{$\mathrm{t}$} & \multirow[t]{2}{*}{ Sig. } \\
\hline & & $\mathrm{B}$ & Std. Error & & & \\
\hline \multirow{3}{*}{1} & (Constant) & ,272 & ,028 & & 9,861 &, 000 \\
\hline & Lag_X1 &,- 038 & ,014 &,- 565 & $-2,756$ & ,008 \\
\hline & Lag_X2 & ,018 & ,009 & 421 & 2,053 &, 046 \\
\hline
\end{tabular}

a. Dependent Variable: Lag_Y

Sumber : data diolah, 2021

Berdasarkan tabel 5, maka persamaan regresi linier berganda yang diperoleh adalah sebagai berikut :

$$
\text { IPI = 0,272 - 0,038IC + 0,018ROGIC+ } \varepsilon
$$

Keterangan:

IPI

IC : Intellectual Capital

ROGIC : Rata - Rata Pertumbuhan Intellectual Capital

$\varepsilon \quad$ : standar error 
Berdasarkan persamaan regresi linier berganda di atas dapat diinterpretasikan sebagai berikut :

1. Koefisien konstanta sebesar 0,272 dengan nilai positif, ini dapat diartikan bahwa islamicity performance index akan bernilai 0,272 apabila masing - masing variabel intellectual capital dan rata - rata pertumbuhan intellectual capital (ROGIC) bernilai 0 .

2. Variabel intellectual capital memiliki koefisien regresi sebesar -0,038. Nilai koefisien regresi negatif menunjukkan bahwa jika setiap kenaikan 1\% variabel intellectual capital, dengan asumsi variabel lain tetap maka akan menurunkan nilai islamicity performance index sebesar 0,038.

3. Variabel dan rata - rata pertumbuhan intellectual capital memiliki koefisien regresi sebesar 0,018. Nilai koefisien regresi positif menunjukkan bahwa jika setiap kenaikan 1\% variabel rata - rata pertumbuhan intellectual capital (ROGIC), dengan asumsi variabel lain tetap maka akan menaikan nilai islamicity performance index sebesar 0,018.

\section{Uji Statistik F (Uji Simultan)}

Uji statistik $\mathrm{F}$ digunakan untuk menunjukan pengaruh variabel independen secara bersama - sama terhadap variabel dependen [24]. Adapun kriteria penerimaan atau penolakan hipotesis sebagai berikut :

1. Jika nilai signifikan $<0,05$ maka $\mathrm{H}_{0}$ ditolak dan $\mathrm{H}_{1}$ diterima. Hal ini berarti variabel independen secara bersama - sama (simultan) berpengaruh terhadap variabel dependen.

2. Jika nilai signifikan $>0,05$ maka $\mathrm{H}_{0}$ diterima dan $\mathrm{H}_{1}$ ditolak. Hal ini berarti variabel independen tidak berpengaruh secara bersama - sama (simultan) terhadap variabel dependen. ini :

Berikut ini adalah hasil uji signifikansi simultan (Uji statistik F) dalam penelitian

Tabel 6. Hasil Uji Statistik F (Uji Simultan)

\begin{tabular}{|c|c|c|c|c|c|c|}
\hline \multicolumn{7}{|c|}{ ANOVA $^{\mathrm{a}}$} \\
\hline & & Sum of Squares & df & Mean Square & $\mathrm{F}$ & Sig. \\
\hline \multirow{3}{*}{1} & Regression & , 152 & 2 & ,076 & 3,797 &, $030^{\mathrm{b}}$ \\
\hline & Residual & ,922 & 46 & ,020 & & \\
\hline & Total & 1,074 & 48 & & & \\
\hline
\end{tabular}

a. Dependent Variable: Lag_Y

b. Predictors: (Constant), Lag_X2, Lag_X1

Sumber : data diolah, 2021

Berdasarkan tabel 6 dapat dilihat bahwa nilai signifikansi lebih kecil dari 0,05 $(0,030<0,05)$ yang berarti $\mathrm{H}_{0}$ ditolak dan $\mathrm{H}_{1}$ diterima. Dapat disimpulkan bahwa variabel independen yaitu intellectual capital (X1) dan rata - rata pertumbuhan intellectual capital (X2) berpengaruh secara bersama - sama (simultan) terhadap variabel dependen islamicity performance index pada Bank Syariah tahun 2015 - 2019 di Indonesia. 


\section{Uji Statistik t (Uji Parsial)}

Uji statistik $\mathrm{t}$ pada dasarnya menunjukkan seberapa jauh pengaruh suatu variabel independen dalam menerangkan variabel dependen [24]. Apabila tingkat signifikansi $\mathrm{t}<\alpha(0,05)$ artinya variabel independen memiliki pengaruh terhadap variabel dependen. Apabila tingkat signifikansi $t>\alpha(0,05)$ artinya variabel independen tidak berpengaruh terhadap variabel dependen.

Berikut ini adalah hasil uji signifikansi parameter individual (Uji statistik t) dalam penelitian ini :

Tabel 7. Hasil Uji Statistik t (Uji Parsial)

\begin{tabular}{|c|c|c|c|c|c|c|}
\hline \multicolumn{7}{|c|}{ Coefficients $^{a}$} \\
\hline \multirow{2}{*}{\multicolumn{2}{|c|}{ Model }} & \multicolumn{2}{|c|}{ Unstandardized Coefficients } & \multirow{2}{*}{$\begin{array}{c}\text { Standardized } \\
\text { Coefficients } \\
\text { Beta }\end{array}$} & \multirow[t]{2}{*}{$\mathrm{t}$} & \multirow[t]{2}{*}{ Sig. } \\
\hline & & $\mathrm{B}$ & Std. Error & & & \\
\hline \multirow{3}{*}{1} & (Constant) & ,272 & ,028 & & 9,861 &, 000 \\
\hline & Lag_X1 &,- 038 & 014 &,- 565 & $-2,756$ & ,008 \\
\hline & Lag_X2 & ,018 & ,009 & ,421 & 2,053 & ,046 \\
\hline
\end{tabular}

a. Dependent Variable: Lag_Y

Sumber : data diolah, 2021

Berdasarkan tabel 7 dapat disimpulkan :

a. Nilai signifikansi intellectual capital (X1) adalah sebesar 0,008. Hal ini menunjukkan bahwa nilai signifikansi lebih kecil dari 0,05 $(0,008<0,05)$ yang berarti $\mathrm{H}_{1}$ diterima. Dapat disimpulkan bahwa intellectual capital secara parsial berpengaruh signifikan terhadap islamicity performance index pada Bank Syariah tahun 2015 - 2019 di Indonesia.

b. Nilai signifikansi rata - rata pertumbuhan intellectual capital (X2) adalah sebesar 0,046 . Hal ini menunjukkan bahwa nilai signifikansi lebih kecil dari 0,05 $(0,046$ $<0,05)$ yang berarti $\mathrm{H}_{1}$ diterima. Dapat disimpulkan bahwa rata - rata pertumbuhan intellectual capital (ROGIC) secara parsial berpengaruh signifikan terhadap islamicity performance index pada Bank Syariah tahun 2015 - 2019 di Indonesia.

\section{Pembahasan}

\section{Pengaruh Intellectual Capital Terhadap Kinerja Bank Syariah Berdasarkan Islamicity Performance Index}

Hasil penelitian menunjukkan bahwa intellectual capital memiliki pengaruh yang signifikan terhadap kinerja Bank Syariah berdasarkan islamicity performance index yang diproksi dengan profit sharing ratio (PSR). Hal ini dapat dilihat dari tingkat signifikansi probabilitas sebesar 0,008 lebih kecil dari 0,05 yang berarti $\mathrm{H}_{1}$ diterima. Hasil penelitian ini konsisten dengan penelitian Harianto \& Syafruddin (2013); Nazra \& Suazhari (2019); Riyandini et al. (2015) yang menunjukan bahwa intellectual capital berpengaruh terhadap kinerja Bank Syariah berdasarkan islamicity performance index. Hasil penelitian ini dapat diartikan bahwa besar kecilnya intellectual capital akan 
berdampak atau berpengaruh pada besar kecilnya kinerja Bank Syariah yang diukur berdasarkan islamicity performance index.

Berdasarkan pendekatan resource based theory perusahaan dapat mencapai keunggulan bersaing yang berkesinambungan dan memperoleh keuntungan maksimal dengan memiliki atau mengendalikan aset-aset strategis baik yang berwujud maupun yang tak berwujud [20]. Berdasarkan teori tersebut, berarti jika Bank Syariah mampu mengendalikan dan memanfaatkan aset tak berwujudnya berupa intellectual capital secara baik, efektif, dan efisien, maka akan mampu mencapai keunggulan bersaing dan memperoleh keuntungan yang maksimal sehingga dapat dinyatakan bahwa Bank Syariah tersebut memiliki kinerja yang baik.

Pada penelitian ini nilai koefisien intellectual capital yang menunjukkan tanda negatif. Arah yang negatif berarti jika terjadi peningkatan intellectual capital maka akan terjadi penurunan kinerja Bank Syariah. Hal ini sejalan dengan hasil penelitian Nazra \& Suazhari (2019) dan Riyandini et al. (2015). Hal ini berarti jika intellectual capital yang diinvestasikan oleh perusahaan semakin besar, maka kinerja Bank Syariah akan semakin menurun. Hal ini dapat disebabkan karena adanya bentuk intellectual capital yang kurang produktif dan adanya trade-off pada komponen intellectual capital [25].

Pengaruh yang negatif antara intellectual capital terhadap kinerja keuangan Bank Syariah berdasarkan islamicity performance index yang diproksi dengan profit sharing ratio (PSR) dapat diakibatkan karena tidak maksimalnya pemanfaatan intellectual capital oleh Bank Syariah. Hal ini dikarenakan masih banyak sumber daya manusia yang bekerja di Bank Syariah tetapi memiliki latar belakang dari bank konvensional, sehingga pengetahuan mengenai Bank Syariah masih belum maksimal. Akibatnya kinerja Bank Syariah itu sendiri tidak dapat dicapai secara maksimal walaupun telah menginvestasikan intellectual capital yang besar. Tidak semua investasi terhadap intellectual capital dapat memberikan keuntungan [26].

\section{Pengaruh Rata - Rata Pertumbuhan Intellectual Capital (ROGIC) Terhadap Kinerja Bank Syariah Berdasarkan Islamicity Performance Index}

Hasil penelitian menunjukkan bahwa rata - rata pertumbuhan intellectual capital (ROGIC) memiliki pengaruh yang signifikan terhadap kinerja Bank Syariah berdasarkan islamicity performance index yang diproksi dengan profit sharing ratio (PSR). Hal ini dapat dilihat dari tingkat signifikansi probabilitas sebesar 0,046 lebih kecil dari 0,05 yang berarti $\mathrm{H}_{2}$ diterima. Hasil penelitian ini konsisten dengan penelitian Baroroh (2014); Harianto \& Syafruddin (2013); Zulaecha \& Pantori (2015) yang menunjukan bahwa rata - rata pertumbuhan intellectual capital (ROGIC) berpengaruh terhadap kinerja Bank Syariah berdasarkan islamicity performance index.

Pada penelitian ini nilai koefisien rata - rata pertumbuhan intellectual capital (ROGIC) menunjukkan tanda positif. Arah yang positif berarti jika terjadi peningkatan rata - rata pertumbuhan intellectual capital maka akan terjadi peningkatan pula pada kinerja Bank Syariah. Bank Syariah dapat memperbaiki kinerjanya jika dapat meningkatkan pertumbuhan intellectual capital yang dimilikinya. Perusahaan harus mampu mengelola dan meningkatkan intellectual capital yang dimilikinya agar dapat tetap unggul [7]. Tingkat rata - rata pertumbuhan intellectual capital berhubungan dengan peningkatan kinerja dimasa sekarang maupun yang akan datang [27] 


\section{Simpulan}

Berdasarkan hasil pengujian dan pembahasan yang telah diuraikan, maka dapat disimpulkan bahwa

1. Intellectual capital (IC) berpengaruh signifikan terhadap kinerja Bank Syariah berdasarkan islamicity performance index yang diproksi dengan profit sharing ratio (PSR). Hubungan yang negatif antara intellectual capital dan islamicity performance index menandakan bahwa tingginya investasi terhadap intellectual capital maka nilai islamicity performance index akan semakin menurun yang berarti kinerja Bank Syairah semakin menurun.

2. Rata - rata pertumbuhan intellectual capital (ROGIC) berpengaruh signifikan terhadap kinerja Bank Syariah berdasarkan islamicity performance index yang diproksi dengan profit sharing ratio (PSR). Hubungan yang positif antara rata rata pertumbuhan intellectual capital dan islamicity performance index menandakan bahwa jika rata - rata pertumbuhan intellectual capital meningkat maka akan semakin tinggi nilai islamicity performance index yang berarti kinerja Bank Syairah semakin meningkat.

\section{Keterbatasan dan Saran}

Penelitian yang telah dilakukan pada dasarnya mempunyai keterbatasan dan kelemahan yang memerlukan penyempurnaan di masa yang akan datang. Adapun beberapa keterbatasan dari penelitian ini antara lain :

1. Variabel independen yang digunakan penelitian ini hanya terbatas pada intellectual capital dan rata - rata pertumbuhan intellectual capital.

2. Kinerja Bank Syariah pada penelitian ini diukur menggunakan islamicity performance index hanya terbatas pada profit sharing ratio.

3. Objek yang digunakan sebagai sampel yang digunakan dalam penelitian ini hanya Bank Syariah.

Berdasarkan keterbatasan yang telah dipaparkan diatas, adapun saran untuk penelitian selanjutnya sebagai berikut :

1. Penelitian selanjutnya diharapkan dapat menambahkan variabel independen lain sehingga dapat lebih memperkaya pembahasan mengenai kinerja Bank Syairah berdasarkan islamicity performance index.

2. Penelitian selanjutnya bisa menambahkan indeks lain dari islamicity performance index.

3. Penelitian selanjutnya disarankan agar dapat menambahkan objek penelitian selain dari Bank Syariah.

\section{Ucapan Terima Kasih (Acknowledgement)}

Tim penulis mengucapkan terima kasih kepada Yayasan Pendidikan Nasional Tridinanti yang telah memberi dukungan moril dan bantuan dana dalam melaksanakan penelitian ini.

\section{Referensi}

[1] Kamelia, Eliyanora, and Gustati, "Pengaruh Financing To Deposit Ratio ( FDR ), Risiko Pembiayaan, Kecukupan Modal, Dana Pihak Ketiga , Suku Bunga , dan 
Inflasi Berdasarkan Laporan Perkembangan Keuangan Syariah Indonesia (2017)," Akunt. dan Manaj., vol. 14, no. 1, pp. 43-57, 2019.

[2] A. N. Khasanah, "Jurnal Nominal / Volume V Nomor 1 / Tahun 2016 Pengaruh Intelektual Capital dan Islamicity Performance Index Terhadap Kinerja Keuangan Perbankan Syariah di Indonesia," J. Nominal, vol. V, no. 6, pp. 1-18, 2016, [Online]. Available: https://journal.uny.ac.id/index.php/nominal/article/view/11473/8328.

[3] R. Khairuni, Zahara, and E. Santi, "Pengaruh Intellectual Capital Dan Mekanisme Corporate Governance Terhadap Kinerja Keuangan Pada Perusahaan Manufaktur Yang Terdaftar Di Bursa Efek Indonesia (BEI) Periode 2015-2017," Akunt. dan Manaj., vol. 14, no. 1, pp. 58-81, 2019, doi: 10.30630/jam.v14i1.86.

[4] M. A. K. Al-Musali and K. N. I. K. Ismail, "Intellectual Capital and its Effect on Financial Performance of Banks: Evidence from Saudi Arabia," Procedia - Soc. Behav. Sci., vol. 164, no. August, pp. 201-207, 2014, doi: 10.1016/j.sbspro.2014.11.068.

[5] D. Maditinos, D. Chatzoudes, C. Tsairidis, and G. Theriou, "The Impact of Intellectual Capital on Firms' Market Value and Financial Performance," J. Intellect. Cap., vol. 12, no. 1, pp. 132-151, 2011, doi: 10.1108/14691931111097944.

[6] N. T and R. Haniffa, "Determinants of Financial Performance of Islamic Banks : An Intellectual Capital Persperctive," J. Islam. Account. Bus. Res., vol. 8, no. 2, pp. 130-142, 2017.

[7] N. Bontis, K. William Chua Chong, and S. Richardson, "Intellectual Capital and Business Performance in Malaysian Industries," J. Intellect. Cap., vol. 1, no. 1, pp. 85-100, 2000, doi: 10.1108/14691930010324188.

[8] V. Dženopoljac, S. Janoševic, and N. Bontis, "Intellectual Capital and Financial Performance in The Serbian ICT Industry," J. Intellect. Cap., vol. 17, no. 2, pp. 373396, 2016, doi: 10.1108/JIC-07-2015-0068.

[9] N. Harianto and M. Syafruddin, "Pengaruh Modal Intelektual Terhadap Kinerja Bisnis Bank Umum Syariah (BUS) Di Indonesia," Diponegoro J. Account., vol. 2, no. 4, pp. 1-10, 2013.

[10] I. Ulum, "Pengaruh Intellectual Capital Terhadap Kinerja Keuangan Perusahaan Perbankan Di Indonesia," 2007.

[11] D. Andraeny and D. D. Putri, "Islamicity Financial Performance Index in Indonesian Islamic Banks," Shirkah J. Econ. Bus., vol. 2, no. 3, 2017, doi: 10.22515/shirkah.v2i3.170.

[12] S. Hameed, A. Wirman, B. Alrazi, M. Nazli, and S. Pramono, "Alternative Disclosure and Performance Measures for Islamic Banks," Second Conf. Adm. Sci. Meet. Challenges Glob. Age, King Fahd Univ. Pet. Miner. Dhahran, Saudi Arab., pp. 19-21, 2004. 
[13] H. D. Ramadhanty, "Pengaruh Intellectual Capital terhadap Kinerja Keuangan Perusahaan Perbankan Umum Syariah yang Terdaftar di Otoritas Jasa Keuangan ( OJK) Tahun 2017-2018," Pros. Manaj., vol. 6, no. 1, pp. 586-589, 2018.

[14] M. Nazra and S. Suazhari, "Pengaruh Modal Intelektual Terhadap Kinerja Keuangan Perbankan Umum Syariah Berdasarkan Islamicity Performance Index," J. Ilm. Mhs. Ekon. Akunt., vol. 4, no. 1, p. 162, 2019, doi: 10.24815/jimeka.v4i1.10807.

[15] S. F. Oniva, Azib, and E. Fauziah, "Pengaruh Intellectual Capital terhadap Kinerja Keuangan Bank Syariah Berdasarkan Islamicity Performance Index (Studi Kasus pada Bank Umum Syariah di Indonesia Periode Tahun 2014-21017)," in Prosiding Keuangan dan Perbankan Syariah, 2019, vol. 5, no. 1, pp. 222-230.

[16] H. E. Zulaecha and R. A. Pantori, "Intelektual Capital dan Kinerja Perusahaan," Din. UMT, vol. I, no. 1, pp. 79-90, 2015.

[17] P. Riyandini, S. Edi, and F. Sri, "Pengaruh Intellectual Capital terhadap Nilai Perusahaan yang Diintervensi oleh Kinerja Keuangan pada Perusahaan yang Listing di Bursa Efek Indonesia (BEI) (Studi Empiris pada Sub Sektor Perbankan Periode Tahun 2011-2014," 2015.

[18] N. Baroroh, "Analisis Pengaruh Modal Intelektual Terhadap Kinerja Keuangan Perusahaan Manufaktur Di Indonesia," J. Din. Akunt., vol. 5, no. 2, pp. 172-182, 2014, doi: 10.15294/jda.v5i2.2997.

[19] N. A. Walidayni, "Modal Intelektual Sebagai Tolak Ukur Perusahaan," Kompasiana, 2017.

[20] B. Wernerfelt, "A Recource-based View of the Firm," Strateg. Manag. J., vol. 5, pp. 171-180, 1984, [Online]. Available: http://onlinelibrary.wiley.com/doi/10.1002/smj.4250050207/abstract.

[21] S. E. R. Meilani, D. Andraeny, and A. Rahmayati, "Analisis Kinerja Perbankan Syariah di Indonesia dengan Menggunakan Pendekatan Islamicity Indices," in Syariah Paper Accounting FEB UMS, 2016, pp. 22-38.

[22] T. A. Stewart, Intellectual Capital:The New Wealth of Organizations. London: United Kingdom: Nicholas Brealey Publishing, 1997.

[23] Pulic, "Measuring The Performance of Intellectual Potential in Knowledge Economy," 1998.

[24] M. Kuncoro, Metode Riset untuk Bisnis dan Ekonomi. Jakarta: Erlangga, 2013.

[25] V. Murthy and J. Mouritsen, "The Performance of Intellectual Capital: Mobilising Relationships Between Intellectual and Financial Capital in a Bank," Accounting, Audit. Account. J., vol. 24, no. 5, pp. 622-646, 2011, doi: 10.1108/09513571111139120.

[26] M. A. Young, M. Subramanian, and S. A. Snell, "Intellectual Capital Profiles: An Examination of Investments and Returns," J. Manag. Stud., vol. 41, no. 2, pp. 335- 
362, 2004, doi: https://doi.org/10.1111/j.1467-6486.2004.00435.x.

[27] H. P. Tan, D. Plowman, and P. Hancock, "Intellectual capital and financial returns of companies," J. Intellect. Cap., vol. 8, no. 1, pp. 76-95, 2007, doi: 10.1108/14691930710715079. 